\title{
Episodic ataxia type 3
}

INSERM

\section{Source}

INSERM. (1999). Orphanet: an online rare disease and orphan drug data base. Episodic ataxia type 3. ORPHA:79135

Episodic ataxia type 3 (EA3) is a very rare form of Hereditary episodic ataxia (see this term) characterized by vestibular ataxia, vertigo, tinnitus, and interictal myokymia. 